\title{
Azadirachta Indica A. Juss: Wood Ash Affects Seedling Growth of Mung Bean Vigna Radiata L.
}

\author{
Sadaf Arshad, Muhammad Zafar Iqbal, Muhammad Shafiq, Mohammad Athar, Muhammad Kabir and \\ Zia-ur-Rehman Farooqui
}

\begin{abstract}
The burning of the wood ash is causing an environmental pollution related issue. The excess concentration of wood ash in the environment normally influenced on plant growth and development. This paper presents the effects of neem wood ash Azadirachta inidca A. Juss.) on germination and seedling growth performance of mung bean (Vigna radiata $\mathrm{L}$.) crop plants. Overall, the data reveals significant $(p<0.05)$ effects of neem wood ash on the different growth variable of mung bean. The treatment of $4-20 \%$ neem wood ash significantly $(p<0.05)$ affected shoot length of mung bean as compared to control. Neem wood ash treatment at all concentration produced fewer toxic effects on root and leaf growth of mung bean. The neem wood ash treatment at $20 \%$ also produced significantly $(p<0.05)$ toxic effects on root and leaf dry weight of mung bean. Whereas, neem wood ash treatment at all level did produce any significant effects on shoot dry weight, total plant dry weight and leaf area ratio of mung bean.
\end{abstract}

Index Terms - Crop, neem, seedling growth, tree, wood ash.

\section{INTRODUCTION}

Wood ash contain micro and macro nutrient and necessary requirement for plant growth and productivity. The ashes are produced from hardwoods, including oak, maple, ash, hickory, sycamore, walnut, apple and cherry. They also produce several times more ash and contain more nutrients than softwoods like pine and fir [1].

The presence of wood ash in excess concentration in the environment may produce beneficial [2] for harmful effect on plant growth. There are few studies has been carried out on the impact of ash on soil and plant growth. The effects of ash on carrot, canola, maize, rice growth parameters, yield, microbial biomass, soil biota and soil physical and chemical properties were reported [3-17]. The significant effects of wood ash fertilization on soil chemical properties of forest soil in three young Scots pine (Pinus sylvestris L.) plantations and a Norway spruce (Picea abies (L.) Karst.) plantation with different site fertility in southern Finland was examined [18]. The different behavior of wood ash on sugarcane also examined [19]. Wood ash application generally improved soil properties, which in turn enhanced maize grain, yield [20].

The combustion of wood ash increases the soil $\mathrm{pH}$ and provides mineral nutrients likewise calcium, magnesium, potassium and phosphorus [21] to plant growth. However, the addition of wood ash can also produce detrimental impact to agricultural crops and the entire chain of production [22]. The possible harmful components in ash are heavy metal(oid)s including cadmium $(\mathrm{Cd})$, lead $(\mathrm{Pb})$, chromium $(\mathrm{Cr})$, and arsenic (As). Similarly, trace elements, such as nickel (Ni), can be present, and, while these elements fulfill a biological role in small quantities, they can be toxic when present beyond optimal thresholds [23]. The wood has high calorific value as a fuel and most widely used for high grade charcoal
[24] it makes a good slow-burning fuel and charcoal [25]. The increasingly high cost of mineral fertilizers and a preferred economic disposal of wood ash had necessitated a research in the use of wood ash to reduce the rate of fertilizer application for crop production [26]. In Asian countries, organic wastes, human and livestock excretions, straw, leaf litter, grass, sewage, rice husk charcoal, and wood ash used as a fertilizers and soil conditioners in agriculture to raise the productivity of crops [27]. Positive effects of wood ash fertilization and weed control on the growth of Scots pine on former peatbased agricultural land recorded [28].

Neem is multipurpose medicinal tree of family Meliaceae, and found in tropical and subtropical areas of the world [29]. Azadirachta indica Adr. Juss commonly known as neem tree, a tree reached up to $15 \mathrm{~m}$ tall. It yields good timber and all parts of the plant are medicinal along with many phytochemical properties. Neem tree is ever green and fastgrowing cultivating tree in China and Indian subcontinent include Bangladesh, Sri Lanka, Nepal, Maldives and China and throughout the warmer parts of the Pakistan.

The mung bean (Vigna radiata (L.) R. Wilczek) is a legume cultivated for its edible seeds and sprouts across Asia [30]. Mung bean crop is cultivating in wide range of ecological conditions of Pakistan and in other Asian countries. Mung bean is utilized in the cereal-based diets and rich in 24\% digestible protein [31-32]. Mung bean [Vigna radiata (L.) Wilczek], is an indigenous vegetable legume and one of the most important pulse crops in Southeast Asia [33] and is an important pulse in Pakistan [34]. In Pakistan, mung bean is usually grown in rotation with wheat, but AVRDC is broadening opportunities for the crop by intercropping it with sugarcane. Mung bean is an important summer legume grown in Pakistan, accounting for $14 \%$ of total pulse production [35]. Mung bean cover an area of 208.5 thousand hectares in Pakistan and 5.5 thousand hectares in Sindh. The average yield in Pakistan as well as in Sindh province has been around $550 \mathrm{~kg} / \mathrm{ha}$ during the last two decades, which is very low as compared to many other countries. There could be many reasons for the low yield but the prominent one is the low yield potential of the land races and the narrow genetic base [36].

Pulses play a vital role in relieving protein malnutrition in many areas where animal protein cannot afford [37]. The scientific literature on the effects of neem wood ash on mung bean crop is scanty in the country. The main objective of this study was to assess the effects of neem wood ash on seedling growth of an important legume crop mung bean cultivating in larger part of Pakistan. 


\section{MATERIALS AND METHODOLOGY}

This experimental study was conducted in the green house at the Department of Botany, University of Karachi, Pakistan, during the month of August - September. The mean temperature was 28 to $32^{\circ} \mathrm{C}$ and relative humidity $65-74^{\circ} \mathrm{C}$. The plant species commonly known as neem (Azadirachta indica (L.) Adelb) and an important legume crop mung bean or green gram (Vigna radiata (L.) R. Wilczek was selected. Ashes made by burning the trunk and branches of neem, after burning, the neem wood ashes were collected in jars and the experiments was conducted in pots. The pots were filled up to $2 / 3$ with soil. The concentrations of the neem wood ashes taken in this experiment were $0,4,8,12,16$ and $20 \%$, respectively. The neem wood ash was mixed with $100 \mathrm{~g}$ of soil [Table 1].

The growth experiment was conducted in pots filled with soil in August - September when mean temperature was 28 $32^{\circ} \mathrm{C}$ and relative humidity was $65-74^{\circ} \mathrm{C}$. The healthy seeds of mung bean were obtained from the local seed store, Karachi and were surface sterilized with $0.2 \%$ solution of sodium hypochlorite $(\mathrm{NaOCl})$ for one minute to avoid any fungal contamination. The experiment was conducted completely randomized design. Beans used in seedling growth experiments were healthy and of uniform size. Seven replicates for each concentration were taken. After mixing ash with the soil, the seeds of mung bean were imbibed in water for half an hour for the purpose to make any type of seed dormancy. Ten seeds of mung bean were sown in each pot and pots were placed in an open field and watered when required. Without wood ash treatment, plant was used as control. The pots were reshuffled weekly to avoid light, shade or any other climatic factor. The plants were irrigated with tap water. After 40 days, the plants were harvested. The growth of mung bean was observed in neem ash including length of shoot and roots, seedling length and leaf area was noted. For dry weights, the root and shoots were dried at $80^{\circ}$ $\mathrm{C}$ for 48 hours in oven.

TABLE 1. The composition of neem wood ash in soil sample.

\begin{tabular}{|c|c|c|}
\hline Treatments & $\begin{array}{c}\text { Neem bark } \\
\text { wood ash }\end{array}$ & soil \\
\hline & & \\
\hline 1 & $0 \mathrm{~g}$ wood ash & 100 gram of soil \\
\hline 2 & $4 \mathrm{~g}$ wood ash & 96 gram of soil \\
\hline 3 & $8 \mathrm{~g}$ wood ash & 92 gram of soil \\
\hline 4 & $12 \mathrm{~g}$ wood ash & 88 gram of soil \\
\hline 5 & $16 \mathrm{~g}$ wood ash & 84 gram of soil \\
\hline 6 & $20 \mathrm{~g}$ wood ash & 80 gram of soil \\
\hline
\end{tabular}

The root shoot ratio, leaf weight ratio, specific leaf area, leaf area ratio was found by following formulas;

Root/ shoot ratio = root dry weight / shoot dry weight Leaf weight ratio = leaf dry weight / total plant dry weight Specific leaf area $\left(\mathrm{cm}^{2} \mathrm{~g}^{-1}\right)=$ Leaf area / leaf dry weight Leaf area ratio $\left(\mathrm{cm}^{2} \mathrm{~g}^{-1}\right)=$ Leaf area / Total plant dry weight

\section{Statistical analyses}

Analysis of variance (ANOVA) and DMRT was calculated according to the procedures of Statistical Analysis System using personnel computer having costat

version 3 . Least significant differences selected at $P \leqslant 0.05$ were used for multiple means comparison tests.

\section{RESULTS AND DISCUSSION}

The effects of neem wood ash (Azadirachta inidca A. Juss.) on seedling growth and seedling dry weight of

The different concentration of neem wood ash affected seedling length of mung bean as compared to control. An increased in concentration of wood ash at $16 \%$ significantly $(\mathrm{p}<0.05)$ decreased seedling length $(29.40 \mathrm{~cm})$ of mung bean as compared to control $(39.8 \mathrm{~cm})$. Wood ash may contain heavy metals. Heavy metals in fly ash from a coal fired power station in Poland reported [39]. The uptake of phytotoxic element from the soil might be cause of reduction in seedling growth of mung bean. Similarly, increased in concentration of neem wood ash treatment at $8-20 \%$ decreased leaf size of mung bean 20.80 sq. cm, 19.30 sq. cm, 14.80 sq. cm, 14.30 sq. cm as compared to control 22.80 sq. cm, respectively. Wood ash has agricultural uses due to its neutralizing power and in addition helps in providing soil nutrients such as $\mathrm{Ca}$, $\mathrm{Mg}, \mathrm{K}$, and $\mathrm{P}$. The effect of wood ash on the mobility of heavy metal(oid)s (As, $\mathrm{Cd}, \mathrm{Cr}, \mathrm{Pb}$, and $\mathrm{Ni}$ ) in the soil-plant-water system, and the nutritional response $(\mathrm{N}, \mathrm{P}$, and $\mathrm{K}$ ) of ryegrass (Lolium perenne L.) under greenhouse in po conditions reported [40]. The application of different concentrations 4 , $8,12,16$ and $20 \%$ of neem wood ash produced variable effect on leaf growth of mung bean as compared to without ash treatment. Neem wood ash treatment at all concentration produced different effects on seedling dry weight of mung bean. The neem wood ash treatment at $16-20 \%$ significantly $(p<0.05)$ affected root and leaf dry weight of mung bean. Whereas, neem wood ash treatment at all level did not produce any significant effects on shoot dry weight, total plant dry weight and leaf area ratio of mung bean. In recent years, there has been a growing interest in the tropical world in using crop residues for improving soil productivity in order to reduce the use of external inputs of inorganic fertilizers [41]. The application of palm bunch ash significantly increased maize grain yield of 4530 and $6120 \mathrm{~kg}$ at the rate of 2 tons for the major and minor rainy seasons, respectively [42].

The present paper also identifies the influence of neem wood ash on the seedling dry weight of mung bean. The dry matter contents of seedlings of mung bean can be related to the decrease in shoot and seedling growth. Application of neem wood ash significantly affected leaf $(0.115 \mathrm{~g})$ and root dry matter $(0.03 \mathrm{~g})$ of mung bean as compared to the control. Wood ash treatment at $20 \%$ increased leaf weight ratio $(0.51)$ as compared to the control (0.39). The effect of rubber wood biochar at 1 and $2 \%$ amendment showed a significant positive effect on aboveground dry matter accumulation of root stock, seedling growth and nutritional status of Hevea nursery plants was determined [43]. 
TABLE 2. The effects of neem wood ash (Azadirachta inidca A. Juss.) on seedling growth and seedling dry weight of mung bean (Vigna radiata $\mathrm{L}$ ).

\begin{tabular}{|c|c|c|c|c|c|c|}
\hline & \multicolumn{6}{|c|}{ Wood ash concentration ( $\%)$} \\
\hline $\begin{array}{l}\text { Growth } \\
\text { parameter }\end{array}$ & $\mathbf{0}$ & 4 & 8 & 12 & 16 & 20 \\
\hline $\begin{array}{l}\text { Shoot length } \\
(\mathrm{cm})\end{array}$ & $\begin{array}{l}28.0 \mathrm{c} \\
\pm 0.71\end{array}$ & $\begin{array}{l}25.12 \mathrm{a} \\
\pm 0.75\end{array}$ & $\begin{array}{l}23.12 c \\
d \\
\pm 0.5\end{array}$ & $\begin{array}{l}21.6 \mathrm{bc} \\
\pm 1.34\end{array}$ & $\begin{array}{r}19.4 \mathrm{ab} \\
\pm 0.89\end{array}$ & $\begin{array}{l}16.9 \mathrm{a} \\
\pm 1.60\end{array}$ \\
\hline $\begin{array}{l}\text { Root length } \\
(\mathrm{cm})\end{array}$ & $\begin{array}{l}11.7 \mathrm{a} \\
\pm 1.50\end{array}$ & $\begin{array}{l}14.2 \mathrm{a} \\
\pm 0.85\end{array}$ & $\begin{array}{l}12.5 \mathrm{a} \\
\pm 1.20\end{array}$ & $\begin{array}{l}13.2 \mathrm{a} \\
\pm 1.80\end{array}$ & $\begin{array}{l}15.1 \mathrm{a} \\
\pm 3.70\end{array}$ & $\begin{array}{l}12.5 \mathrm{a} \\
\pm 0.84\end{array}$ \\
\hline $\begin{array}{l}\text { Seedling } \\
\text { length } \\
(\mathrm{cm})\end{array}$ & $\begin{array}{l}39.8 \mathrm{~b} \\
\pm 1.8\end{array}$ & $\begin{array}{l}39.3 \mathrm{~b} \\
\pm 1.12\end{array}$ & $\begin{array}{l}35.6 \mathrm{ab} \\
\pm 1.78\end{array}$ & $\begin{array}{l}34.8 \mathrm{ab} \\
\pm 2.51\end{array}$ & $\begin{array}{l}34.5 \mathrm{ab} \\
\pm 4.59\end{array}$ & $\begin{array}{l}29.4 \mathrm{a} \\
\pm 2.28\end{array}$ \\
\hline $\begin{array}{c}\text { Leaf area } \\
\text { (sq.cm) }\end{array}$ & $\begin{array}{l}22.8 \mathrm{a} \\
\pm 4.98 \\
\end{array}$ & $\begin{array}{l}23.1 \mathrm{a} \\
\pm 6.39 \\
\end{array}$ & \begin{tabular}{|l|}
$20.8 \mathrm{a}$ \\
\pm 2.97 \\
\end{tabular} & \begin{tabular}{|l|}
$19.3 \mathrm{ab}$ \\
\pm 1.17 \\
\end{tabular} & $\begin{array}{l}14.8 \mathrm{a} \\
\pm 1.48 \\
\end{array}$ & $\begin{array}{r}14.3 \mathrm{a} \\
\pm 4.08 \\
\end{array}$ \\
\hline $\begin{array}{c}\text { Root dry } \\
\text { weight } \\
\text { (g) }\end{array}$ & $\begin{array}{l}0.0775 a \\
b \pm 0.02\end{array}$ & $\begin{array}{l}0.155 b \\
\pm 0.55\end{array}$ & $\begin{array}{l}0.040 \mathrm{a} \\
\pm 0.01\end{array}$ & $\begin{array}{l}0.0750 \mathrm{ab} \\
\pm 0.22\end{array}$ & $\begin{array}{l}0.112 \mathrm{ab} \\
\pm 0.01\end{array}$ & $\begin{array}{l}0.030 \mathrm{a} \\
\pm 0.001\end{array}$ \\
\hline $\begin{array}{l}\text { Shoot dry } \\
\text { weight } \\
\text { (g) }\end{array}$ & $\begin{array}{l}0.195 \mathrm{a} \\
\pm 0.035\end{array}$ & $\begin{array}{l}0.132 b \\
\pm 0.16\end{array}$ & $\begin{array}{l}0.212 \mathrm{a} \\
\pm 0.061\end{array}$ & $\begin{array}{l}0.0155 \mathrm{a} \\
\pm 0.023\end{array}$ & $\begin{array}{l}0.182 \mathrm{a} \\
\pm 0.025\end{array}$ & $\begin{array}{l}0.100 \mathrm{a} \\
\pm 0.033\end{array}$ \\
\hline $\begin{array}{c}\text { Leaf dry } \\
\text { weight } \\
(\mathrm{g}) \\
\end{array}$ & $\begin{array}{l}0.180 \mathrm{ab} \\
\pm 0.021\end{array}$ & $\begin{array}{l}0.122 \mathrm{a} \\
\pm 0.02\end{array}$ & $\begin{array}{l}0.220 \mathrm{~b} \\
\pm 0.043\end{array}$ & $\begin{array}{l}0.145 \mathrm{ab} \\
\pm 0.16\end{array}$ & $\begin{array}{l}0.145 \mathrm{ab} \\
\pm 0.02\end{array}$ & $\begin{array}{l}0.115 \mathrm{a} \\
\pm 0.014\end{array}$ \\
\hline $\begin{array}{c}\text { Total plant } \\
\text { dry weight } \\
(\mathrm{g})\end{array}$ & $\begin{array}{l}0.452 \mathrm{a} \\
\pm 0.046\end{array}$ & $\begin{array}{l}0.410 \mathrm{a} \\
\pm 0.09\end{array}$ & $\begin{array}{l}0.472 \mathrm{a} \\
\pm 0.012\end{array}$ & $\begin{array}{l}0.375 \mathrm{a} \\
\pm 0.53\end{array}$ & $\begin{array}{l}0.440 \mathrm{a} \\
\pm 0.063\end{array}$ & $\begin{array}{l}0.245 \mathrm{a} \\
\pm 0.043\end{array}$ \\
\hline $\begin{array}{c}\text { Root / shoot } \\
\text { ratio }\end{array}$ & \begin{tabular}{|c|}
$0.465 a$ \\
\pm 1.16 \\
\end{tabular} & $\begin{array}{l}1.09 \mathrm{~b} \\
\pm 0.29 \\
\end{array}$ & \begin{tabular}{|r|}
$0.234 \mathrm{a}$ \\
\pm 0.08 \\
\end{tabular} & $\begin{array}{l}0.472 \mathrm{a} \\
\pm 0.077 \\
\end{array}$ & $\begin{array}{r}0.629 \mathrm{a} \\
\pm 0.07 \\
\end{array}$ & $\begin{array}{l}0.309 a \\
\pm 0.03 \\
\end{array}$ \\
\hline \begin{tabular}{|c|} 
Leaf weight \\
ratio
\end{tabular} & $\begin{array}{l}0.398 \mathrm{ab} \\
\pm 0.03 \\
\end{array}$ & $\begin{array}{l}0.308 \mathrm{a} \\
\pm 0.2 \\
\end{array}$ & \begin{tabular}{|l|}
$0.475 \mathrm{a}$ \\
\pm 0.02 \\
\end{tabular} & \begin{tabular}{|}
$0.395 \mathrm{a}$ \\
\pm 0.29 \\
\end{tabular} & $\begin{array}{r}0.325 \mathrm{a} \\
\pm 0.01 \\
\end{array}$ & $\begin{array}{r}0.511 \mathrm{a} \\
\pm 0.09 \\
\end{array}$ \\
\hline $\begin{array}{l}\text { Specific leaf } \\
\text { area }\left(\mathrm{cm}^{2} \mathrm{~g}^{-}\right. \\
1)\end{array}$ & $\begin{array}{l}121.6 \mathrm{ab} \\
\pm 13.84\end{array}$ & $\begin{array}{l}187.0 \mathrm{~b} \\
\pm 29.4\end{array}$ & $\begin{array}{l}97.88 \mathrm{a} \\
\pm 6.85\end{array}$ & $\begin{array}{l}137.2 \mathrm{ab} \\
\pm 14.18\end{array}$ & $\begin{array}{l}111.4 \mathrm{ab} \\
\pm 21.1\end{array}$ & $\begin{array}{l}135.9 \mathrm{ab} \\
\pm 50.5\end{array}$ \\
\hline $\begin{array}{c}\text { Leaf area } \\
\text { ratio }\end{array}$ & \begin{tabular}{|l}
$48.92 \mathrm{a}$ \\
\pm 7.04 \\
\end{tabular} & \begin{tabular}{|l}
$55.58 \mathrm{a}$ \\
\pm 4.9 \\
\end{tabular} & $\begin{array}{l}46.94 \mathrm{a} \\
\pm 5.40 \\
\end{array}$ & \begin{tabular}{|l}
$54.28 \mathrm{a}$ \\
\pm 6.84
\end{tabular} & \begin{tabular}{|l}
$35.77 \mathrm{a}$ \\
\pm 6.09
\end{tabular} & $\begin{array}{l}58.29 \mathrm{a} \\
\pm 10.10 \\
\end{array}$ \\
\hline
\end{tabular}

\section{CONCLUSION}

The results conclude that variable changes in seedling growth of mung bean including root, shoot, seedling length, leaf size and seedling dry weight were related to increase in concentration of neem wood ash from $4-20 \%$ as compared to control (without ash) in soil. The treatment of neem wood ash at $20 \%$ significantly $(\mathrm{p}<0.05)$ affected shoot and seedling length, seedling dry weight of mung bean (Vigna radiata) as compared to control treatment.

\section{ACKNOWLEDGMENT}

We are grateful to Chairman, Department of Botany and the University authorities for providing us space and facilities for conducting the thesis research work.

\section{REFERENCES}

[1] D. Fosdick, D. Wood ash properly used can help soil, gardens, and lawns. The Columbian. https:/www.columbian. com/news/2018/ nov/15/wood-ash-properly-used-can-help-soil-gardens-lawns/. Visited on 4 December 2018.

[2] Napoleon, 2018. Benefit and uses of wood ash. https://napoleonfireplaces.com/benefits-and-uses-of-wood-ash/. Accessed on 4 December 2018

[3] G. P. Sparling, C.D.A. McLay, C.. Tang and C.. Raphael, Effect of short-term legume residue decomposition on soil acidity. Australian Journal of Soil Research, vol. 37 no. 3:561 - 574.. 1999.
[4] P.K. Sarangi, D. Mahakur and P.C. Mishra. Soil biochemical activity and growth response of rice Oryza sativa in fly ash amended soil. Bioresource Technology vol. 76: 199-205. 2001.

[5] S. Kesh, N. Kalra, S.K. Sharma and A. Chaudhary. Fly ash incorporation effects on soil characteristics, growth and yield of wheat. Asia Pacific Journal of Environmental Development, vol. 4:5369. 2003.

[6] L.R. Basher, C.W. Ross and j. Dando. Effects of carrot growing on volcanic ash soils in the Ohakune area, New Zealand. Australian Journal of Soil Research vol. 42 no. 3: 259 - 272. 2004.

[7] J. Kucharski, E. Jastrzebska and J. Wyszkowska,. Contamination of soil with hard coal ash as modifier of physicochemical and biological properties of soil. Electronic Journal of Polish Agricultural University vol. 9: 35. 2006.

[8] C. Steiner, W.G. Teixeria, J. Lehmann, T.. Nehls, J.L.V. de Macedo, W.E.H. Blum and W. Zech. Long-term effects of manure, charcoal and mineral fertilization on crop production and fertility on a highly weathered Central Amazonian upland soil. Plant and Soil, vol. 291: 275-290. 2007.

[9] L. S. Ayeni, O.M., O.P. Oso and S.O. Ojeniyi. Effect of sawdust and wood ash applications in improving soil chemical properties and growth of cocoa (Theobroma cacao) seedlings in the nurseries. Medwel Agricultural Journal, vol.3: 323-326. 2008.

[10] J. Major, M. Rondon, D. Molina, S. J. Riha and J. Lehmann. Maize yield and nutrition during 4 years after biochar application to a Colombian savanna oxisol. Plant and Soil, vol 333: 117-128. 2003.

[11] V. Manoharan, I.A.M. Yunusa, P. Loganathan, R. Lawrie, B. R. Murray, C.G. Skilbeck, and D. Eamus, D. Boron contents and solubility in Australian fly ashes and its uptake by canola (Brassica napus L.) from the ash-amended soils. Australian Journal of Soil Research, vol. 48 no. 480-487. 2010.

[12] J. Lehmann, M.C. Rillig, J. Thies, J., C.A. Masiello, W. C. Hockaday and D. Crowley. Biochar effects on soil biota: a review. Soil Biology \& Biochemistry, vol.43, 1812-1836. 2011.

[13] R.E. Masto,, Md A. Ansari, J. George, V.A. Selvi and L.C Ram. Coapplication of biochar and lignite fly ash on soil nutrients and biological parameters at different crop growth stages of Zea mays. Ecological Engineering, vol. 58: 314-322. 2013.

[14] A.K. Nayak, A. Kumar, A., R. Raja, K.S. Rao, S. Mohanty, M. Shahid, R, Tripathy, B.B. Panda and P. Bhattacharyya. Fly ash addition affects microbial biomass and carbon mineralization in agricultural soils. Bulletin of Environmental Contamination and Toxicology vol. 92: 160-164. 2014.

[15] S. Munda, A.K. Nayak, P.N. Mishra, P. Bhattacharyya, S. Mohanty, A. Kumar, U. Kumar, M.J. Baig, R. Tripathi, M. Shahid, T. Adak and V.K. Thilagam. Combined application of rice husk biochar and fly ash improved the yield of lowland rice. Soil Research, vol. 54 no. :451-459. 2016..

[16] D. Sulivan,. Wood ashes can benefit gardens and lawns. https://extension.oregonstate.edu/ node /81951 visited on 10-09-2018.

[17] S. Arshad, M.Z. Iqbal and M. Shafiq. The influence of buttonwood ash application on growth of cowpea seedling. Asian Journal of Research in Botany, vol. 2 no. 3: 1-6. 2019. F. Grau, H. Choo, J.W. Hu and J. Jung. Engineering behavior and characteristics of wood ash and sugarcane Bagasse Ash. Materials, vol. 8: 6962-6977. 2015.

[18] A. Saarsalmi,, E. Mälkönen. and S. Piirainen. Effects of wood ash fertilization on forest soil chemical properties. Silva Fennica, vol.35 no. 3: 355-368. 2001.

[19] F. Grau, H. Choo, J.W. Hu and J. Jung. Engineering behavior and characteristics of wood ash and sugarcane Bagasse Ash. Materials, vol. 8: 6962-6977. 2015.

[20] C.N. Mbah, J.N. Nwite and I.A. Nweke,. Response of maize (Zea mays L.) to different rates of wood-ash application in acid ultisol in Southeast Nigeria. African Journal of Agricultural Research, vol. 5 no. 7: 580-583. 2010.

[21] L. Augusto, M.R. Bakker and C.. Meredieu. Wood ash applications to temperate forest ecosystem potential benefits and drawbacks. Plant Soil. vol. 306:181-198. 2008.

[22] Y. Rodríguez, B. Maudier, E. Zagal and P. Hernández. Effects of wood ash on nutrients and heavy metal(oid)s mobility in an Ultisol. International Journal of Environmental Research and Public Health, vol. 16 no. 7: 1246. 2019.

[23] B. Seshadri, N. Bolan and R. Naidu. Rhizosphere-induced heavy metal(loid) transformation in relation to bioavailability and remediation. J. Soil Sci. Plant Nutr. Vol. 15:524-548. 2015.

[24] J. F. Morton. Atlas of medicinal plants of middle America. Bahamas to Yucatan. C.C. Thomas, Springfield, IL. 1981.

[25] E.L. Jr. Little, Common fuelwood crops: a handbook for their identification. McClain Printing Co., Parsons, WV. 1983. 
[26] S. Adjei-Nsiah, S. Response of Maize (Zea mays L.) to different rates of Palm Bunch ash application in the semi-deciduous forest agroecological zone of Ghana. Applied and Environmental Soil Science, Article ID 870948, 5 pages, https://doi.org /10. $1155 / 2012 / 870948$

[27] M. Ogawa and Y. Okimori. Pioneering works in biochar research, Japan. Australian Journal of Soil Research, vol. 48 no. 7: 489-500. 2010.

[28] J. Hytönen, P. Jylhä and K. Little. Positive effects of wood ash fertilization and weed control on the growth of Scots pine on former peat-based agricultural land - a 21-year study. Silva Fennica, vol. 51 no. 3): article id 1734. https://doi.org/10.14214/sf.1734. 2017.

[29] Saleem, S., G. Muhammad, M.A. Hussain and S.N.A. Bukhari. A comprehensive review of phytochemical profile, bioactives for pharmaceuticals, and pharmacological attributes of Azadirachta indica. Phytother Res. Vol. 32 no. 7: 1241-1272. 2018.

[30] C. Heuzé, K.J. Heywood, D.O. Stevens and J.K. Ridley. Changes in global ocean bottom properties and volume transports in CMIP5 models under climate change scenarios. Journal of Climate, vol. 28: 2917-2944. 2015.

[31] G.S.S. Khattak, M. Ashraf, T . Elahi and G. Abbas. Selection for large seed size at the seedling stage in mung bean (Vigna radiata $(\mathrm{L}$.) Wilczek). Breed. Sci. vol. 53: 141-143. 2003a

[32] G.S.S. Khattak,R. Zamir, T Muhammad S.A. Shah. Breeding mung bean (Vigna radiata (L.) Wilczek) genotypes for the agro climatic conditions of NWFP. Pak. J. Bot. 35: 763-770. 2003b.

[33] M.A. Mansoor, Z. Islam, S. Muhammad, M. Umair, M. Ayaz, A, Khan, $\mathrm{M}$, Asif and Y. Sakina. New high yielding mung bean [(Vigna radiata L.) Wilczek] variety "Inqalab Mung" for the agro-climatic conditions of KPK. Pakistan Journal of Agricultural Research, vol. 30 no. 2: 173179.2017.

[34] M.S. Riaz and Z.Z Ahmad. Mung bean production manual. World vegetable center. https://worldveg.tind.io/record/66217? $\mathrm{ln}=$ enVisited on 6 December 2018.

[35] World Vegetable Centre (W.V.C.). Sweet future of mung bean in Pakistan. https://avrdc.org/ sweet-future-mungbean-pakistan/. Accessed on 6 December 2018.

[36] M.A. Siddiqui. Crops. Mung bean http://www.nia.org.pk/gin\%20 mungbean.html. Accessed on 6 December 2018.

[37] A. Chandrakala, A. R. Prabha, D. Chitra, S. Murlidharan and S Saravanababu. Toxic potential of neem ash powder (Azadirachta indica A. Juss) against callososobruchusu chinensis infestation (Bruchide: Coleoptera) on the cow pea (Vigna unguiculata) seeds. International Journal of Pure and Applied Zoology, vol. 1 no. 1: 5260. 2013.

[38] M. Marx, B. Marschner and P.N. Nelson. Short-term effects of incubated legume and grass materials on soil acidity and $\mathrm{C}$ and $\mathrm{N}$ mineralisation in a soil of northeast Australia. Australian Journal of Soil Research vol. 40 no. 7:1231 - 1241. 2002.

[39] D.S. Danielowska. Heavy metals in fly ash from a coal-fired power station in Poland. Polish Journal of Environmental Studies, vol. 15: 943-946. 2006.

[40] Y. Rodríguez, B. Maudier, E. Zagal and P. Hernández. Effects of wood ash on nutrients and heavy metal(oid)s mobility in an Ultisol International Journal of Environmental Research and Public Health vol. 16 no. $7: 1246.2019$

[41] F.O. Adekayode and M. R. Olojugba. The utilization of wood ash as manure to reduce the use of mineral fertilizer for improved performance of maize (Zea mays L.) as measured in the chlorophyll content and grain yield. Journal of Soil Science and Environmental Management, vol.1: 40-45. 2010.

[42] S. Adjei-Nsiah. Response of Maize (Zea mays L.) to different rates of Palm Bunch ash application in the semi-deciduous forest agroecological zone of Ghana. Applied and Environmental Soil Science, Article ID 870948, 5 pages, https://doi.org /10. 1155 /2012/870948. 2012.

[43] R.S. Dharmakeerthi, J.A.S. Chandrasiri and V.U. Edirimanne. Effect of rubber wood biochar on nutrition and growth of nursery plants of Hevea brasiliensisestablished in an Ultisol. SpringerPlus, 1:84. 2012. https://doi.org/10.1186/2193-1801-1-84

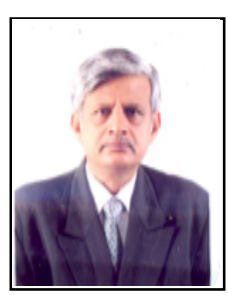

Sadaf Arshad is a researcher in the field of Botany and post graduated from Department of Botany, University of Karachi, Karachi- 75270, Pakistan. Sadaf Arshad has keen interest in research and has written few articles in international peer reviewed scientific journals.

Author's formal photo

Dr. Muhammad Zafar Iqbal (M.Z.I.) is with Department of Botany, University of Karachi, Karachi- 75270, Pakistan. Prof. Dr. Muhammad Zafar Iqbal former Charmian, Department of did his Ph.D. from England. He is engaged in teaching and research work in the same department since 1973 and has published more than 150research papers in the field of plant ecology, sociology and environmental pollution. His research is recognized at national and internationally level and supervised five $\mathrm{Ph}$. D. student. (email: mziqbalbotuokpk@yahoo.com)

Author's formal
photo

Dr. Muhammad Shafiq P.G.D. (P.A.), M.A.S. (H.R.), M.Sc. Ph.D. is a freelance research scholar in Department of Botany, University of Karachi, Pakistan and obtained $\mathrm{Ph}$. D. botany, degree in 2002 from University of Karachi, Pakistan. The area of research interest is focuses since 1985, on the plant ecology/ environmental pollution/ heavy metal toxicity and tolerance in plants / allelopathy/ seed germination and seedling growth behavior of plants growing along the busy roads/ automobile pollution. Dr. M. Shafiq has published more than 100 scientific research papers in national and international scientific peer reviewed renowned scientific journals. He has a published a book "Impact of Automobile Pollutants on Plants" and Poison Land. "Vegetation of disturbed and polluted areas in Pakistan" by Strategic book publishing \& rights agency, U.S.A. Research projects completed on phytosociology, research project participation in social sector and research project as Co-Principal Investigator sponsored by Higher Education Commission, Government of Pakistan vide research project No. 20-1073/R\&D/07 from 2008-2011.. He has received research productivity awards twice from Ministry of Science and Technology, Government of Pakistan.

(email:, shafiqeco@yahoo.com)

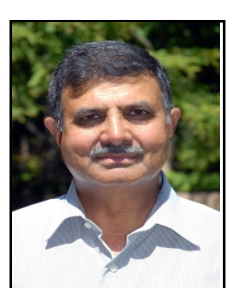

Prof. Dr. Mohammad Athar Tariq, DSc is with California Department of Food and Agriculture, 2800 Gateway Oaks Drive, Sacramento, CA 95833, USA. Dr. Tariq did Ph.D. (1995) in Natural Resources from Utah State University, USA. University of Karachi conferred upon him the first D.Sc. in Botany in 2007. Dr. Tariq has special expertise in agricultural biotechnology and environmental sciences. He has been actively involved in agricultural research for the last 35 years. His publications include many original scientific papers and book chapters. (e-mail: athar.tariq@cdfa.ca.gov).

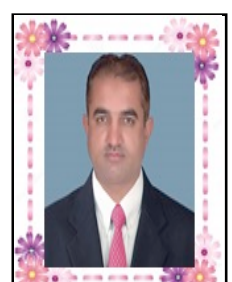

Dr. Muhammad Kabir is Assistant Professor and with Department of Biological Sciences, University of Sargodha, Sub-campus, Bhakkar, Punjab, Pakistan. Dr. Muhammad Kabir born on 15th July, 1982, in district Chakwal of the Punjab (Pakistan). Dr. Kabir did Ph.D. on the "Effects of Industrial Pollution on tolerance \& distribution of Plants" in 2014. Dr. Kabir also completed Higher Education Commission (HEC) research project No. 20-1073/R\&D/07 from 20082011. On 19th June, 2017, joined University of Sargodha, Sub-Campus Bhakkar (Punjab) as an Assistant Professor of Botany and on August 29, 2017, appointed as Incharge, Department of Biological Sciences. Dr. Kabir is Higher Education Commission approved Ph.D. Supervisor and guiding many M.Phil. students and similarly many are under supervision. Dr. Kabir received the Research Productivity Award (RPA) in 2011 and 2012 from the Pakistan Council of Science and Technology (PCST), Islamabad. (E- Mail: muhammad.kabir@uos.edu.pk) 


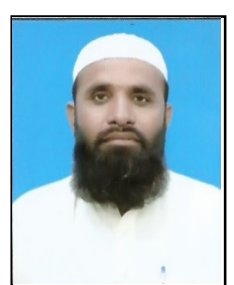

Dr. Zia-ur-Rehman Farooqi born in 1st October 1978 in a village Allah Rakha, Teh. Khanur, District Rahimyar Khan, Province Punjab of Pakistan and got early education from Govt. Primary School Basti Gulabian. Dr. Z.R. Farooqi passed Matriculation Examination in 1994 from Board of Intermediate and Secondary Education Bahawalpur and graduated from Islamia University Bahawalpur in 2001. Dr. Z. R.

Farooqi completed his M.Sc. Botany from Federal Urdu University of Arts, Science and Technology in 2004 and completed professional education (B.Ed.) from Islamia University Bahawalpur in 2005. Dr. Z. R. Farooqi completed Ph.D. in Botany from University of Karachi in 2014 under research title as "EFFECTS OF AUTOMOBILE POLLUTION AND TOLERANCE IN PLANTS". Dr. Faroqi taught in different public schools and colleges from 2005 to 2011, passed Sindh Public Service Commission examination, and joined Govt. Degree Boys College Metroville, S.I.T.E., Karachi as a Lecturer in Botany in 2011. Dr. Farooqi was awarded the Research Productivity Award from Pakistan Council for Science and Technology in 2011 and 2012 on the recognition of research activities and have published 30 research papers in National and International Journals (e-mail: farooqi_bot@yahoo.com) 